\title{
Causes of Coastal Erosion and Environmental Damage on the Sowan Beach of Tuban District
}

\author{
Marita Ika Joesidawati ${ }^{1)}$, Suwarsih ${ }^{1)}$ \\ 1) Program Study of Marine Science, Faculty of Fisheries and Marine Science, \\ Universitas PGRI Ronggolawe, Tuban, Indonesia.
}

\begin{abstract}
Beaches in Tuban district consist mainly of rocky, sandy, muddy, and biogenic beaches (mangroves and corals) with a beach length of $65 \mathrm{~km}$. Factors that cause coastal erosion and environmental degradation in coastal areas are due to natural and human activities. Management policies that ignore the degradation of the coastal environment will result in misleading policies. The purpose of this study is to identify the causes of erosion and damage to the environment of Sowan beach which is a coastal tourist attraction in Tuban Regency. Coastal vulnerability assessment was done by using scoring on seven parameters of human activities. Primary data to determine population activities that influence erosion and damage to the coastal environment was done by distributing questionnaires randomly to 100 communities around Sowan Beach. Based on the results of the Sowan beach vulnerability scoring because human activities indicate conditions that are very vulnerable, a strategy is needed to reduce human activities that are detrimental to Sowan's coastal environment. the results of the vulnerability score of Sowan Beach caused by human activities indicate that conditions are very vulnerable, so a strategy is needed to reduce human activities that are detrimental to Sowan's coastal environment. The results of the vulnerability score of Sowan beach caused by human activities indicate that conditions are very vulnerable, so a strategy is needed to reduce human activities that are detrimental to Sowan's coastal environment. Based on community perceptions, there are 4 destructive human activities; the absence of coastal protection (30\%), the presence of wild sand mining (35\%), tourism activities themselves (20\%) and capture fisheries activities (15\%).
\end{abstract}

Keywords: Coastal Vulnerability Assessment, Tourism, Human Activities

\section{INTRODUCTION}

Coastal erosion is a worldwide marine hazard, because it not only causes loss of land on the coast, beach and tidal zones but also damages infrastructure facilities in coastal areas, induces sea water intrusion and flood hazards. The study of coastal erosion in developed countries began in the early 20th century. (Micallef et al, 2018; Toimil et al, 2017; Matthews et al, 2017)

Coastal erosion is caused due to natural factors such as waves action, tidal currents, wind (Escudero-Castillo et al, 2018; Pikelj et al, 2018) and also due to human activities (Pagán, et al 2016; Chen, \& Bau, 2016). The concept of coastal erosion is the process of eroding coastal constituent material by waves and the scraped material is transported elsewhere by the current. From the point of view of the balance of interactions between forces originating from land and forces emanating from the sea, coastal erosion occurs because the forces originating from the sea are stronger than the forces originating from the land and are destructive in nature. Coastal erosion can also be caused by sea level rise (Taborda \& Ribeiro, 2015; Joesidawati et al, 2017; Joesidawati \& Suntoyo, 2017; López-Dóriga et al, 2019)

Such erosion can cause a reduction in the coastal area, especially the area closest to sea water. If this is allowed to continue, abrasion will erode all coastal areas so that the seawater will inundate all coastal areas and population settlements, Bhattachan et al, 2018), eliminate coastal biodiversity (López-Dóriga et al, 2019) and ecological balance (Yang \& Chui, 2017) and pose a danger both directly and indirectly to human life and the natural environment (Carless et al, 2017). It has been reported that $70 \%$ of the world's sandy beaches are eroding (Bird et al., 1985).

The beaches in Tuban district consist mostly of rocky, sandy, muddy, and biogenic beaches (mangroves and corals). Sandy beaches and muddy beaches are two basic types of beaches consisting of alluvial land (Joesidawati, 2016). The danger of coastal erosion is mainly distributed in these two types of beaches, where on both types of coastline the average coastline decline is $0.13 \mathrm{~m} / \mathrm{yr}$. (Joesidawati and Suntoyo, 2016) 
International Journal of Applied Engineering Research ISSN 0973-4562 Volume 14, Number 12 (2019) pp. 2952-2959

(C) Research India Publications. https://dx.doi.org/10.37622/IJAER/14.12.2019.2952-2959

\section{MATERIALS AND METHODS}

\section{Study Area}
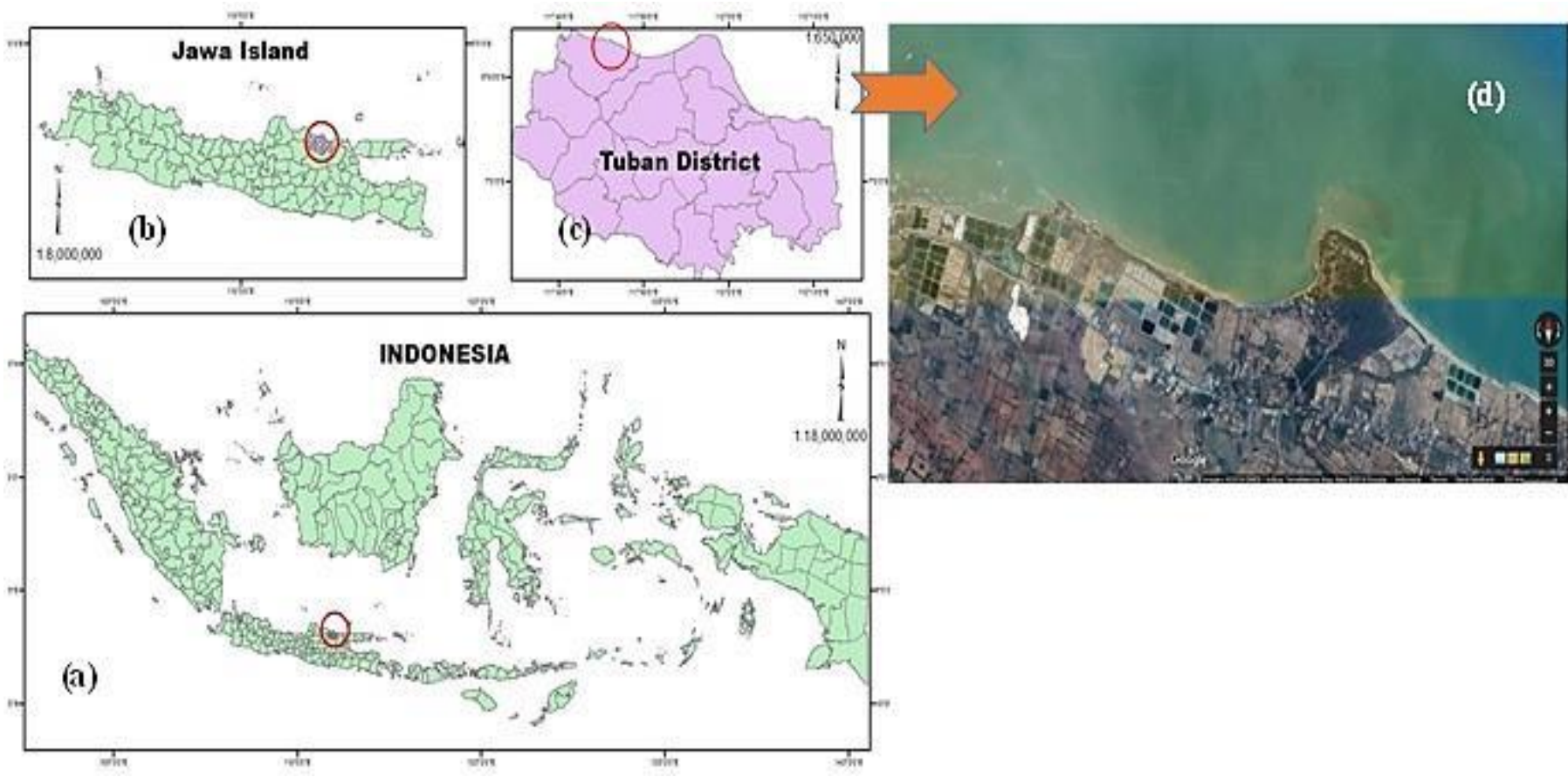

Figure 1 (a) Research location on the map of Indonesia (b) Research sites on the island of Java, precisely Tuban District (c) Research sites in Tuban District (d) Location of research around the coast of Sowan Beach

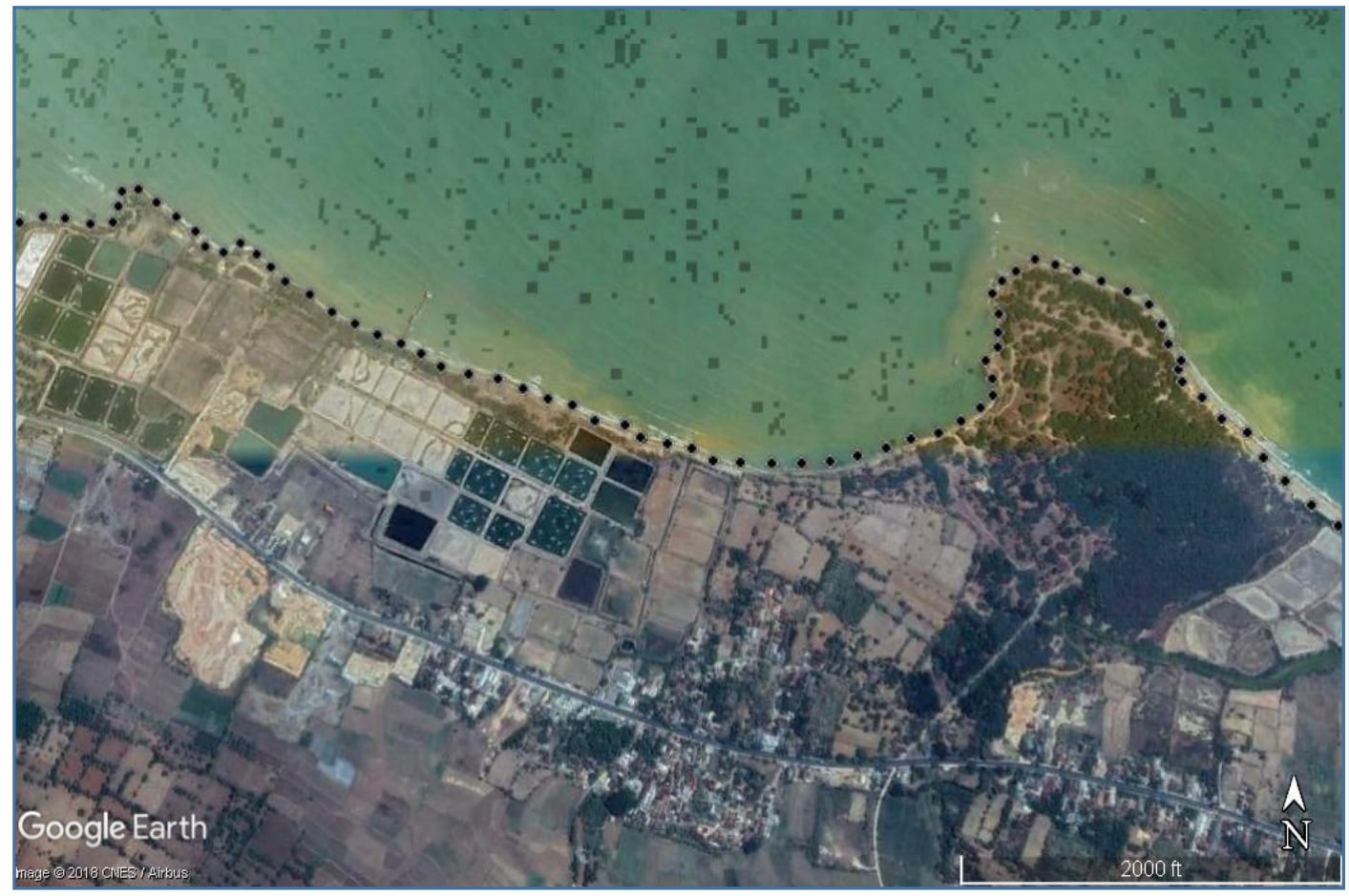

Figure 2. Location points (70 location points) for observing the causes of coastal erosion

Based on Figure 1. Around Sowan Beach is located in Tuban Regency, East Java Province, Indonesia, precisely at coordinates $6^{\circ} 46^{\prime} 30.06 \mathrm{NS}, 111^{\circ} 46^{\prime} 11.18^{\prime \prime} \mathrm{E}$ and $6^{\circ}$ $46 ' 15.78$ "S, $111^{\circ} 44^{\prime} 57.02^{\prime \prime} \mathrm{E}$ with a beach length of $3.5 \mathrm{~km}$ where there are 70 locations that are $50 \mathrm{~m}$ away from one point to another. 


\section{Data Collection and Data Analysis}

Primary data to find out the livelihood activities of the population that influence coastal erosion, as well as identify population perceptions of coastal erosion that occurs, and tourism-related activities at the research site. Primary data was carried out by distributing questionnaires randomly to 100 residents around Sowan beach. Furthermore, simultaneous field observations were carried out with questionnaire surveys to determine the causes of erosion around the study area.

Coastal vulnerability index assessment based on human activities ( 7 parameters) grouped in 5 classes; invulnerable, low vulnerable, moderately vurnerable, vulnerable and highly vulnerable (Table 1)

Table 1. Coastal Vulnerability Assessment based on Human Activity Parameters

\begin{tabular}{|c|c|c|c|c|c|c|}
\hline \multirow[t]{2}{*}{ No } & \multirow[t]{2}{*}{ Parameter } & \multicolumn{5}{|c|}{ Value/vulnerability classes } \\
\hline & & Invulnerable & low vulnerable & moderately vurnerable & vulnerable & highly vulnerable \\
\hline & & 1 & 2 & 3 & 4 & 5 \\
\hline 1 & Sand mining & $>80 \%$ & $60-80 \%$ & $40-60 \%$ & $20-40 \%$ & $<20 \%$ \\
\hline 2 & Coastal reclamation & $<5 \%$ & $5-20 \%$ & $20-30 \%$ & $30-50 \%$ & $>50 \%$ \\
\hline 3 & Ground Water Consumption & $>20 \%$ & $20-30 \%$ & $30-40 \%$ & $40-50 \%$ & $>50 \%$ \\
\hline 4 & Land use pattern & Protected area & Unclaimed area & settlement & Industry & Farming \\
\hline 5 & Natural protection against degradation & $>80 \%$ & $60-80 \%$ & $40-60 \%$ & $20-40 \%$ & $<20 \%$ \\
\hline 6 & Coastal protection structure & $>50 \%$ & $30-50 \% 2$ & $20-30 \%$ & $5-20 \%$ & $<5 \%$ \\
\hline 7 & Watershed & Not affected & & Moderately affected & & Highly affected \\
\hline
\end{tabular}

Source :Joesidawati, (2016)

The chi square method is used as an analysis of data collected based on the results of the questionnaire, and descriptive analysis describes the results of the questionnaire (Senevirathna et al, 2018).

\section{RESULTS AND DISCUSSION}

The cause of coastal erosion which leads environmental damage on coastal areas around Sowan Beach, Bancar is human activity. Joesidawati (2016) analyzed the vulnerability of Tuban beach due to the impact of SLR (Sea Level Rise) using 6 parameters; sand mining, coastal reclamation, groundwater consumption, land use patterns, protection of nature, coastal structures. Human activities can increase the negative impact of rising sea levels and also have an impact on the amount of erosion on the coast of Tuban district. However, in this study, seven parameters were added, including the presence or absence of data on watersheds in the study location. The erosion conditions around the Sowan Beach are based on field observations as shown in Figure 3 

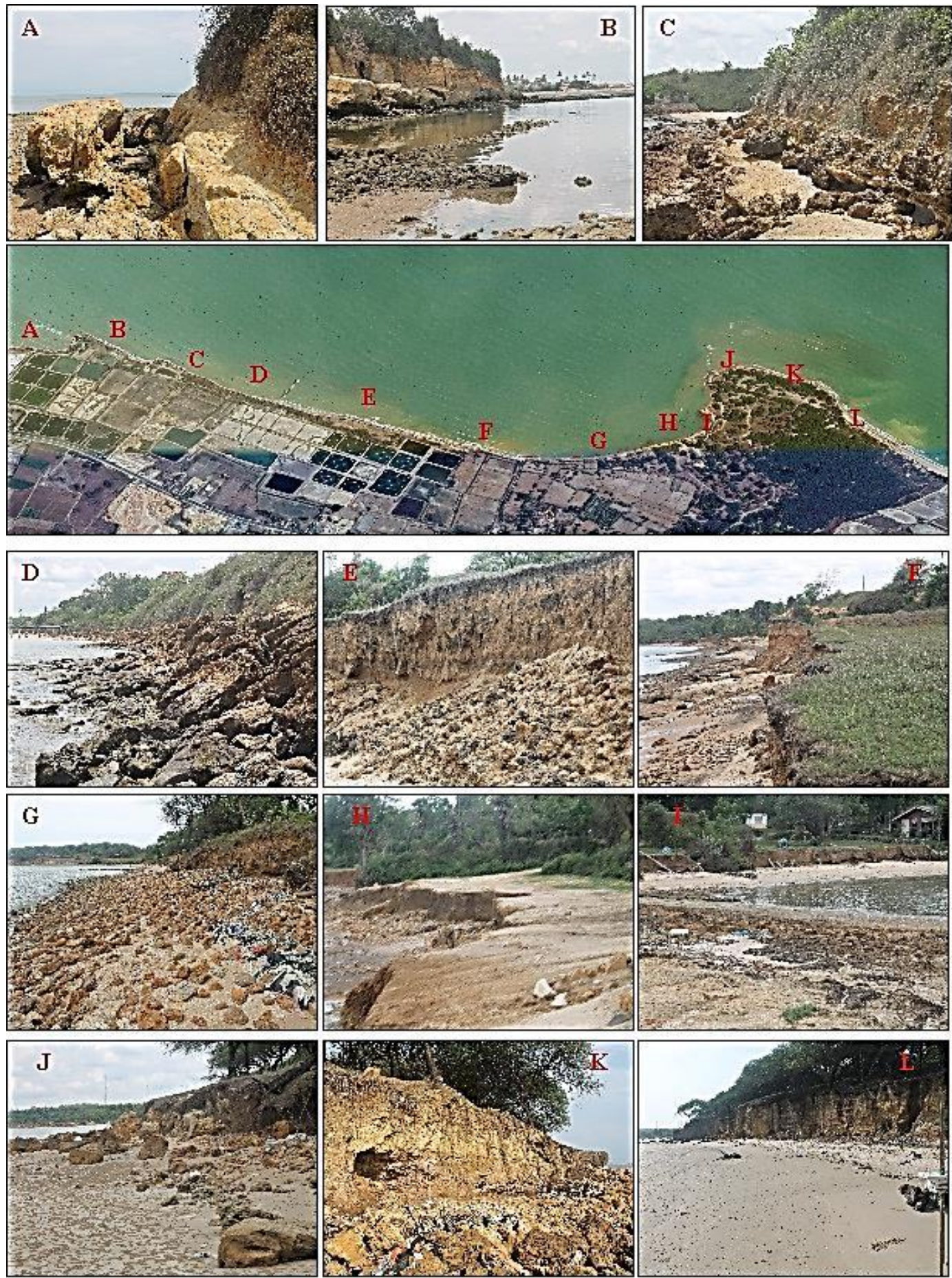

Figure 3. Multiple Point Samples Location of 2017 Field Observation Results on Beach Erosion Conditions along Sowan Beach $( \pm 3.5 \mathrm{~km})$ (12 points from 70 points)

\section{Assessment Coastal Vulnerability Index Based on Seven Human Activitiy Parameters}

\section{Sea- sand Mining}

Illegal sea-sand mining in Tuban district occurs in three subdistricts of coastal area; Bancar, Tambakboyo, and Jenu with a length of beach at the mine is $5420.23 \mathrm{~m} / 5.4 \mathrm{~km}$.. Compared to the length of the coast of Tuban Regency $( \pm 65$ $\mathrm{km}$ ), the location used as illegal mining is $8.48 \%$ (Joesidawati,
2016). Illegal sea-sand mining can affect coastal areas to be more vulnerable (Ozyurt, 2007). Figure 4 shows the illegal sand mining around the Sowan beach the research location) is located in Bogorejo village. The production of sea-sand in the mine are coordinated by sea-sand middlemen. 

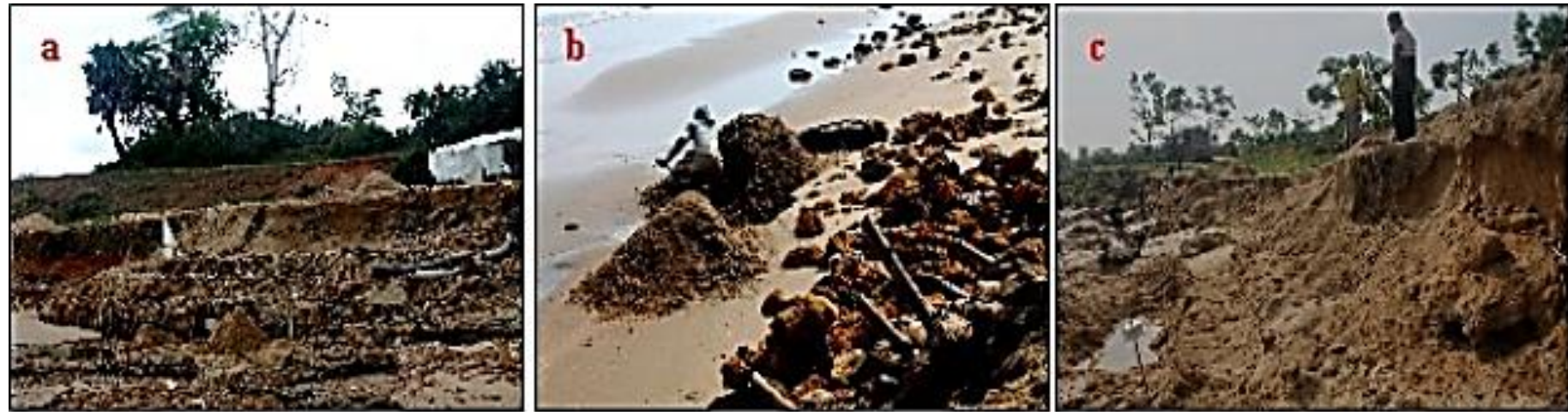

Figure 4. Illegal sand mining around Sowan Beach (Bogorejo Village)

Illegal sand mining around Sowan beach is $856.25 \mathrm{~m}$ or $30.98 \%$ of the length of the coast of Bogorejo Village, Bancar District. The beach vulnerability index using the vulnerability class from Joesidawati (2016) shows that sand mining in Sowan falls into the category of "vulnerable" class

\section{Beach Reclamation}

There was no beach reclamation carried out by the community around Sowan beach, this means the class of vulnerability around Sowan beach in the class "invulnerable"

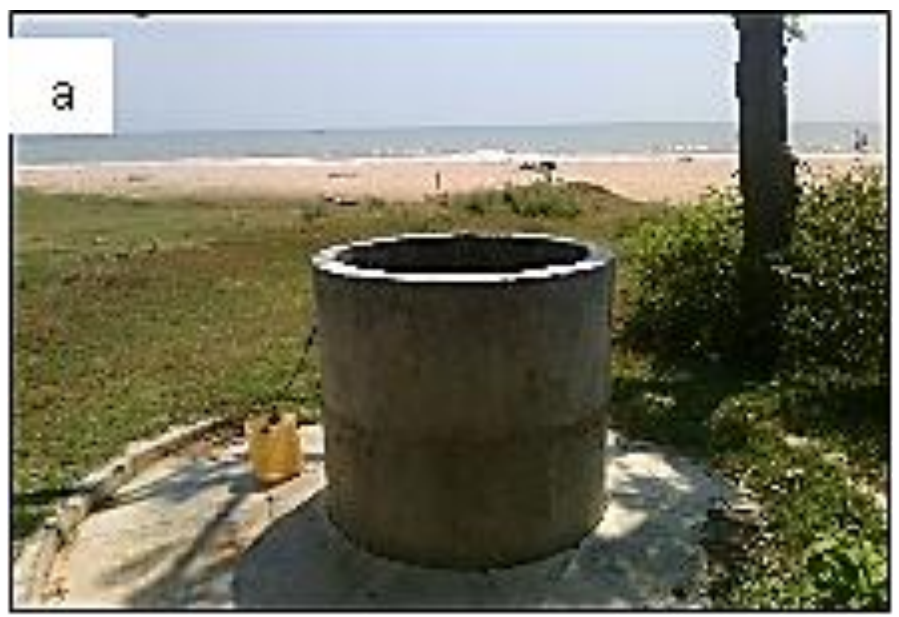

Figure 5. (a) The distance from the artesian wells along the Sowan coast is $\pm 200-300 \mathrm{~m}$ from the shoreline and (b) the distance between the artesian wells is $\pm 50 \mathrm{~m}$

\section{Land Use Pattern}

Land use pattern in the study location was seen at a distance of 300 meters from the shoreline as shown in Figure 6 


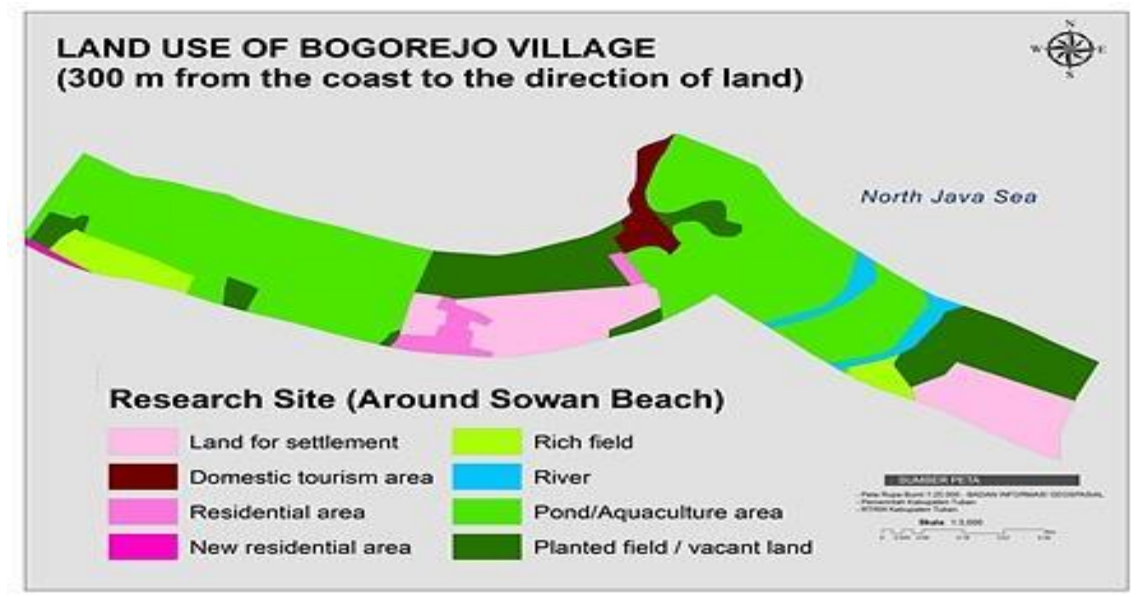

Figure 6. Land Use of Research Sites

Figure 6 shows planted field / vacant land 153,854.54 m2, domestic tourism area $=20,995.61 \mathrm{~m} 2$, rice field $=34,235.30$ $\mathrm{m} 2$, pond $=423,640.15 \mathrm{~m} 2$, river $=21,549.06$, land for settlement $=145,885.86 \mathrm{~m} 2$. Based on the vulnerability class, this region shows the class of "vulnerable" this is because the agricultural area is $76.45 \%$ or $611,729.99 \mathrm{~m} 2$, residential area $18.23 \%$ or $145,885.86 \mathrm{~m} 2$, protected area $2.62 \%$ or $20,995.61$ $\mathrm{m} 2$, unclaimed area of $2.69 \%$ or $21,549.06 \mathrm{~m} 2$

\section{Natural protection against degradation}

Natural protection against degradation according to Dahuri (2003) indicates the presence or absence of key habitats (coral reefs, seagrass beds, and mangrove forests). The existence of tropical marine ecosystems can maintain economic stability in coastal areas throughout the world. (Hoegh-Guldberg et al, 2009; Foale et al, 2013). In the study location there was no natural protection so that it can be included in the class "highly vulnerable"

\section{Coastal Protection Structure}

One of the ways to overcome coastal erosion is by building a coastal protection building (jetty, groynes, breakwater, beach wall or revetment). With the building protruding or parallel to the coastline, it will certainly have an influence on the shape of the existing coastline. Coastal protection structure at the study site which has been built from 2013-2015 by the regional government of Tuban, or by the community, which is only $314.43 \mathrm{~m}$ or $11.38 \%$ of the coastal length of the research site (2,763.94). This condition shows that the class is "highly vulnerable"

\section{Watershed}

The watershed around the coast of Sowan is subwatershed Budur (Figure 7).
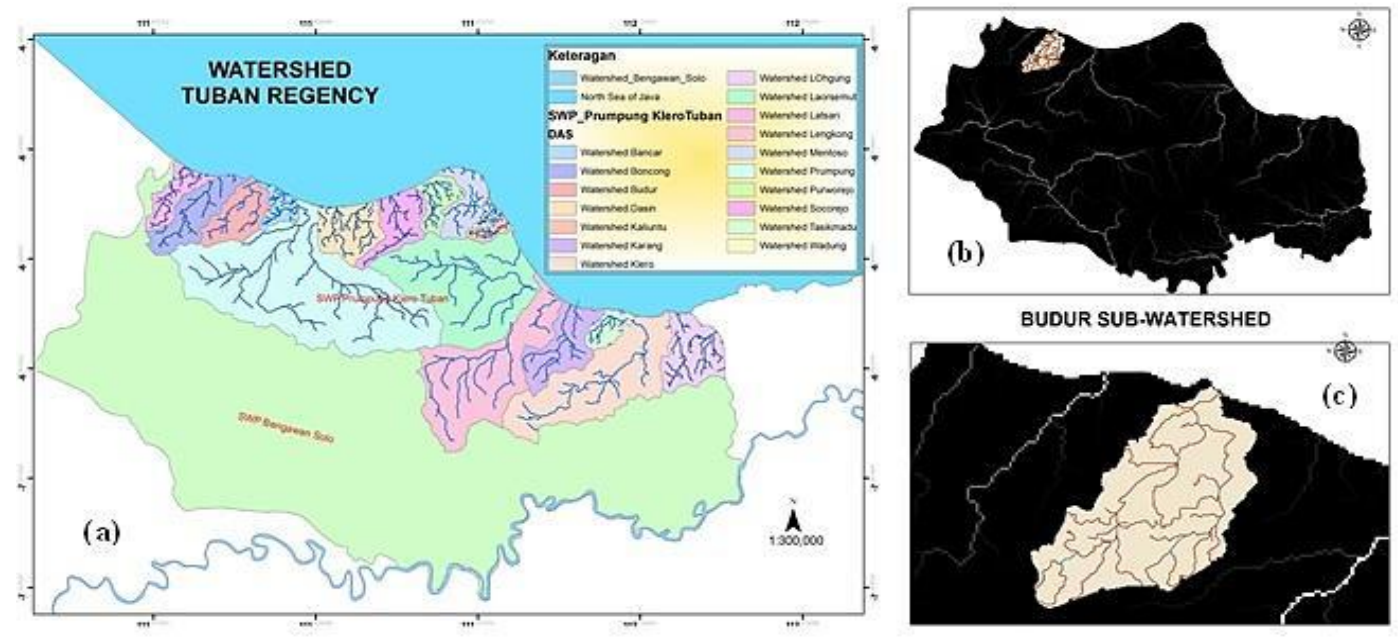

Figure 7. (a) Watersheds in Tuban Regency, (b) and (c) Budur Sub-Watershed which flow on Sowan Beach 
Based on Figure 7, the Sowan beach is strongly influenced by the budur river flow. This condition shows that the class is "highly vulnerable"

\section{Community Perception of the Causes of Erosion and Environment Damage to Sowan Beach}

The causes of erosion around the beach are based on community perceptions as shown in Figure 8

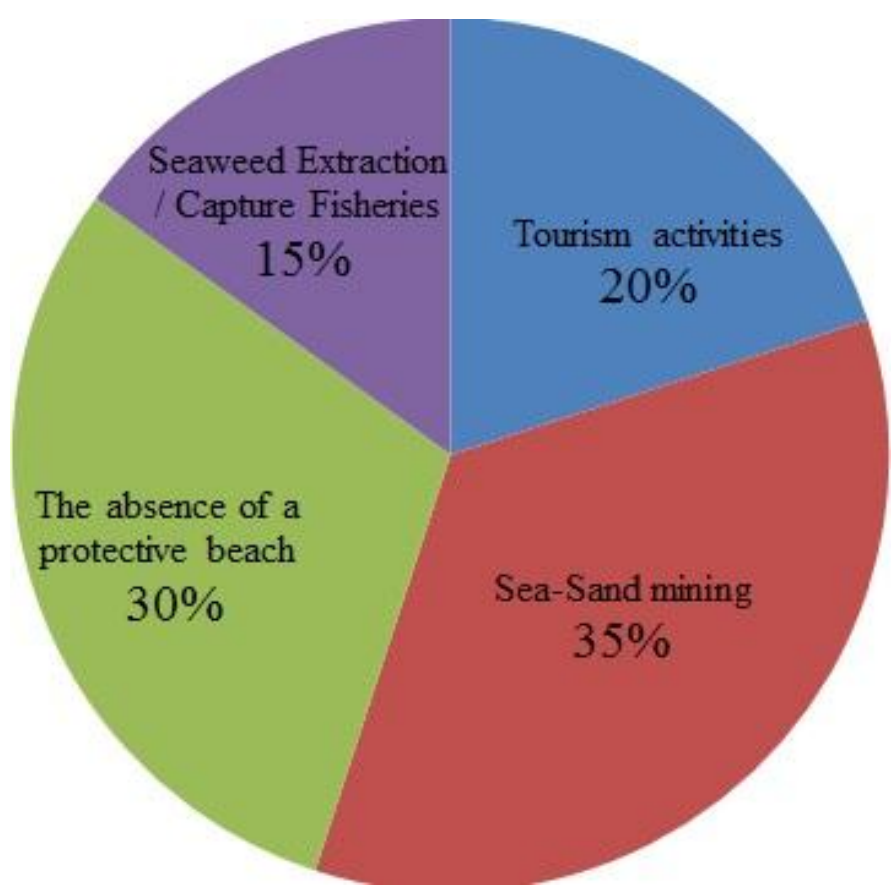

Figure 8 Reasons for coastal erosion and environmental damage according to community perceptions

Figure 8 shows the causes of erosion and damage to the coastal environment from the point of view of the community around the Sowan Coast. According to analysing the results of questionnaires of 100 residents around the study area, one of the factors influencing the increase in coastal erosion intensity is the absence of coastal protectors, even though the community has informed that there is a need for coastal protection for local governments, but there is no right solution to reduce the situation.

Anthropogenic activities that cause erosion and damage to the coastal environment come from the activities of illegal sand miners. One-hundred (100) residents answered that illegal miners were not native Bogorejo people, but they came from some others village around Bogorejo, some even said they did not know where the illegal miners who accidentally took the sea sand around Sowan Beach,

Tourism activities are not a cause of coastal erosion, but are a cause of damage to the coastal environment. The development of infrastructure facilities is one of the factors that cause damage to the natural environment, such as the existence of a number of restaurants, guest houses, the use of boats to develop tourism industry at Sowan Beach . Disposal of waste from restaurants and guesthouses is an important factor in damaging or degrading the environment. This is due to the absence of management or rules in garbage disposal. Waste that is directly discharged into the sea. Other problems are air and noise pollution activities such as marine charity, camp activities, festivals and garbage burning activities.

The activity of seaweed extraction and fishing is also one of the causes of Sowan's coastal damage. Some fishermen in fishing use fishing gear that is not environmentally friendly. In taking seaweed, fishermen usually enter the coral reef area, they can destroy the existing coral reefs

\section{CONCLUSION}

Erosion and damage to the coastal environment have occurred on Sowan Beach which is one of the tourism areas in Tuban district. Based on the results of the scoring assesment of coastal susceptibility to human activities, it shows that the average Sowan coast is highly vulnerable, so a strategy is needed to reduce the level of vulnerability of the coast to human activities. Based on community perceptions, the main causes of erosion and environmental damage of Sowan Beach are caused by 4 activities, namely the absence of coastal protection, the presence of wild sand mining, tourism activities themselves and capture fisheries activities.

\section{ACKNOWLEDGMENTS}

Special thanks to forestry service officials and the tourism agency of Tuban Regency who were stationed in the Sowan beach area for their support during the research as well as the community around the Sowan beach area so that this research went well

\section{REFERENCES}

[1] Bhattachan, A., Jurjonas, M. D., Moody, A. C., Morris, P. R., Sanchez, G. M., Smart, L. S Seekamp, E. L. (2018). Sea level rise impacts on rural coastal social-ecological systems and the implications for decision making. Environmental Science \& Policy, 90, 122-134.

[2] Bird, E. C. F. (1985), Coastline Changes, Wiley \& Sons, New York, 219 pp.

[3] Carless, S. J., Green, J. A. M., Pelling, H. E., \& Wilmes, S.-B. (2016). Effects of future sea-level rise on tidal processes on the Patagonian Shelf. Journal of Marine Systems, 163, 113-124.

[4] Chen, C.-L., \& Bau, Y.-P. (2016). Establishing a multi-criteria evaluation structure for tourist beaches in Taiwan: A foundation for sustainable beach tourism. Ocean \& Coastal Management, 121, 88-96.

[5] Dahuri, R. (2003). Keanekaragaman Hayati Laut. Aset Pembangunan Berkelanjutan Indonesia. PT Gramedia Pustaka. Utama. Jakarta. hal 63, 64 
[6] Escudero-Castillo, M., Felix-Delgado, A., Silva, R., Mariño-Tapia, I., \& Mendoza, E. (2018). Beach erosion and loss of protection environmental services in Cancun, Mexico. Ocean \& Coastal Management, 156, 183-197.

[7] Foale, S., Adhuri, D., Aliño, P., Allison, E.H., Andrew, N., Cohen, P., Evans, L., Fabinyi, M., Fidelman, P., Gregory, C., Stacey, N., Tanzer, J., Weeratunge, N., (2013). Food security and the Coral Triangle Initiative. Mar. Policy 38, 174-183. doi:10.1016/j.marpol.2012.05.033

[8] Hoegh-Guldberg, O., Hoegh-Guldberg, H., Veron, J.E.N., et al., (2009). The Coral Triangle and Climate Change: Ecosystems, People and Societies at Risk. WWF Australia, Brisbane.

[9] Joesidawati, M.I, (2016). Klasifikasi Pantai Di Pesisir Tuban Jawa Timur. Prosiding Seminar Nasional Perikanan dan Kelautan VI, Fakultas Perikanan dan Ilmu Kelautan, Universitas Brawijaya. ISBN: 978-602-72784-1-7

[10] Joesidawati, M.I, (2016). Studi perubahan Iklim dan kerusakan Sumberdaya Pesisir di Kabupaten Tuban. Disertasi. Fakultas Teknologi Kelautan Institut Teknologi Sepuluh Nopember Surabaya. pp 273

[11] Joesidawati, M.I. \& Suntoyo. (2017). Shoreline Changes in Tuban District in East Java Caused by Sea Level Rise Using Bruun Rule and Hennecke Methods. Applied Mechanics and Materials. Ocean Science and Coastal Engineering Vol. 862, pp. 3440. Joesidawati, M.I, Suntoyo, Wahyudi, \& K. Sambodho, (2017). Sea Level Rise on Tuban Coast in East Java and its Consistenty with MAGICC/SCENGEN Prediction. Applied Mechanics and Materials. Vol. 862, pp. 83-89

[12] Joesidawati,M.I \& Suntoyo, (2016). Shoreline Change in Tuban district, East Java using Geospatial and Digital Shoreline Analysis System (DSAS) Techniques. International Journal of Oceans and Oceanography. Volume 10, Number 2 (2016), pp. 235-246

[13] López-Dóriga, U., Jiménez, J. A., Valdemoro, H. I., \& Nicholls, R. J. (2019). Impact of sea-level rise on the tourist-carrying capacity of Catalan beaches. Ocean \& Coastal Management, 170, 40-50. Taborda, R., \& Ribeiro, M. A. (2015). A simple model to estimate the impact of sea-level rise on platform beaches. Geomorphology, 234, 204-210.

[14] Matthews, Y., Scarpa, R., \& Marsh, D. (2017). Using virtual environments to improve the realism of choice experiments: A case study about coastal erosion management. Journal of Environmental Economics and Management, 81, 193-208.

[15] Micallef, S., Micallef, A., \& Galdies, C. (2018). Application of the Coastal Hazard Wheel to assess erosion on the Maltese coast. Ocean \& Coastal Management, 156, 209-222.
[16] Ozyurt ,G., (2007). Vulnerability of Coastal Areas to Sea Level Rise: A Case Study on Göksu Delta. Ankara, Turkey: Middle East Technical University, Master's thesis, pp 99.

[17] Pagán, J. I., Aragonés, L., Tenza-Abril, A. J., \& Pallarés, P. (2016). The influence of anthropic actions on the evolution of an urban beach: Case study of Marineta Cassiana beach, Spain. Science of The Total Environment, 559, 242-255. doi:10.1016/j.scitotenv.2016.03.134

[18] Pikelj, K., Ružić, I., Ilić, S., James, M. R., \& Kordić, B. (2018). Implementing an efficient beach erosion monitoring system for coastal management in Croatia. Ocean \& Coastal Management, 156, 223 238.

[19] Senevirathna, E.M.T.K., K.V.D. Edirisooriya, S.P. Uluwaduge, K.B.C.A. Wijerathna. (2018). Analysis of Causes and Effects of Coastal Erosion and Environmental Degradation in Southern Coastal Belt of Sri Lanka Special Reference to Unawatuna Coastal Area,Procedia Engineering, Volume 212: 1010-1017 ISSN 1877-7058,

[20] Taborda, R., \& Ribeiro, M. A. (2015). A simple model to estimate the impact of sea-level rise on platform beaches. Geomorphology, 234, 204-210.

[21] Toimil, A., Losada, I. J., Camus, P., \& Díaz-Simal, P. (2017). Managing coastal erosion under climate change at the regional scale. Coastal Engineering, $128,106-122$.

[22] Yang, Y., \& Chui, T. F. M. (2017). Aquatic environmental changes and ecological implications from the combined effects of sea-level rise and land reclamation in Deep Bay, Pearl River Estuary, China. Ecological Engineering, 108, 30-39. 